\title{
角鋼管接合部の研究 (その6)
}

正会員鷲尾健 三* 同 ○黒羽啓 明**

まえがき 第 1 図の様な角鋼管接合部では、接手板 や角鋼管ウエブの Scheiben 的な剛性・強度に比して、 角鋼管フランヂの Platten 的な剛性・強度が甚だ小さい ために、これら 3 つ面の交点に応推中を生じるそ のため、この部分が非常に早く降伏して、弾性域は最大 街重の 20〜 50\% にすぎない。 本接合部はな打荷重の増大に酎 え、大きな塑性変形を生してか ら破断するのが通常である。故 飞実用的な立場から、本接合部 の “强さ”の判定の規準を決め るために、弾性的な性質からだ けでは不充分であることを既に のベた1)。

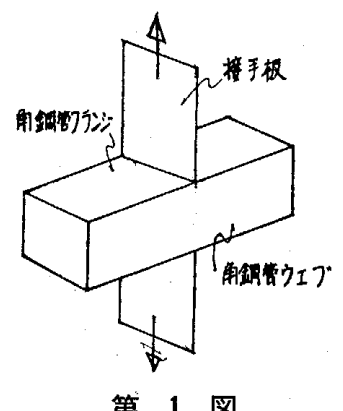

接合部の塑性的な挙動 前報1では、本接合部の強 さを接手板の有効巾で表わした。例えば、この有効巾は 武験体 $V^{\prime}-3-5$ の場合では次表の如くになる(とび離れ た值は平均から除外した)。

\begin{tabular}{|c|c|c|c|}
\hline & 弾性範围 & 降伏荷重時 & 最大荷重時 \\
\hline $\begin{array}{l}\text { 塞 䍂 } \\
\text { 算 }\end{array}$ & $\begin{array}{l}4.58 \mathrm{t} \\
3.23 \mathrm{t}\end{array}$ & $\begin{array}{l}8.21 \mathrm{t} \\
7.09 \mathrm{t}\end{array}$ & $9.96 \mathrm{t}$ \\
\hline
\end{tabular}

(注) $\mathbf{t}:$ 接手板板厚

上の如く、有効门は 荷重の増大するに従い 大きくなるが、接手板 の全币が有効とはなら ない。この性質は接手 板の応力分布形でも明 らかである(第2図)。

第 3 図は角鋼管部分 の歪を Gage Length の小さい抵抗線丕ゲー ジ (G.L. $=4 \mathrm{~mm})$ で測

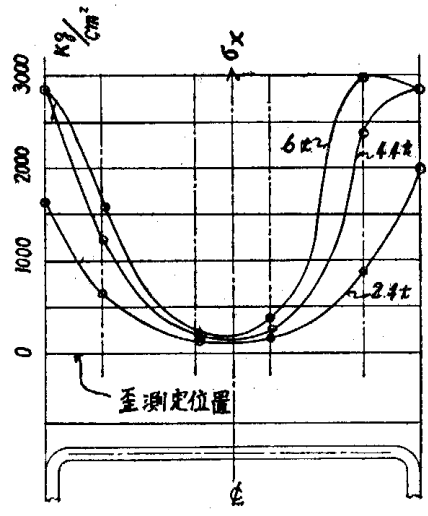

第 2 図
定した結果である。局部的な応力状態は 3 次元的で極め て複雑であるが、角鋼管のフランヂの一部と、溶接隅肉 部分とを逆 $\mathrm{T}$ 形梁の如き単純な模型に置き換え、 $\sigma_{\boldsymbol{y}}$ や $M_{Y}$ の分布形を考えると、荷重の一部がこの様な梁の煎 断力と釣合うことが判る。接手板の両端部が降伏して、 降伏領域が内側へ搪がり、更に上述の梁が降伏して荷重 の増加分を負担し得なくなる応力状態を仮定して求めた 接手板の有効门は、第 3 図で接手板の端部から $\sigma_{y}, M_{y}$ が最大になる部分までの巾と大たい一致する。

載荷前と破壊後の接手板の板厚の変化をマイクロメー

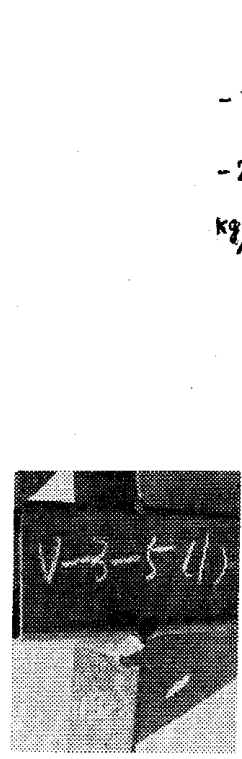

写真 1

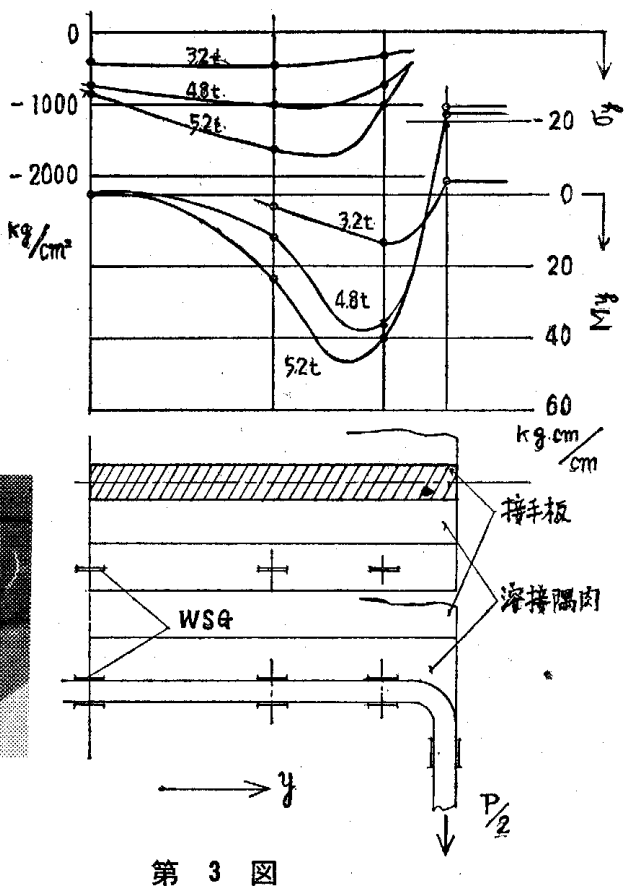

第 3 図

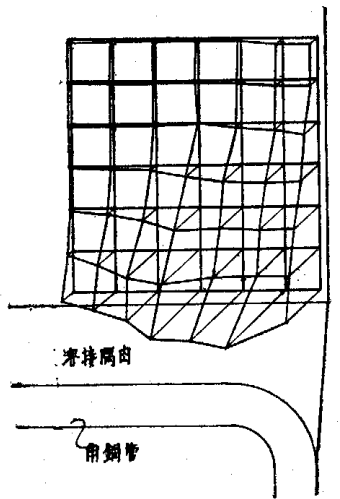

第 4 図

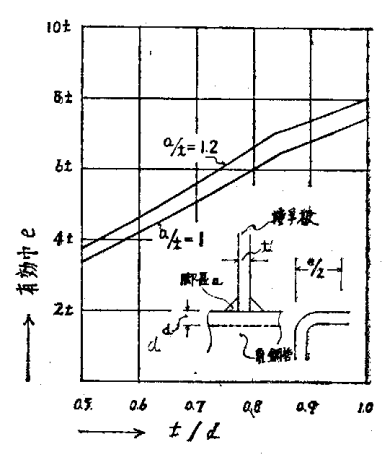

第 5 図
ター $(1 / 100 \mathrm{~mm})$ で測定した結果を第 4 図に示す。接于 板の両端部では、塑性変形のため板厚の減少が著しいこ とが判る。

接合部は応力集中部分の板や溶接隅肉の破断によつて 破壊した（写真 1 ）。：溶接隅肉が破断した時には、最大 荷重のバラつきが大きいが、溶接の出来、不出来がてれ の原因であると考えられる。

設計図表降伏荷重は接合部が大きい塑性変形を始 める直前の荷重段階であるので、接合部の安全な範团を 示す標準の 1 つに用い得ると思われる。第 5 図は、板厚 ・溶接の脚長等の関係が図示の如き場合の降伏荷重時の 有効门を計算したもので、設計荷重を $P$ 、安全率を $S$ 、 材料の降伏点を $\sigma_{Y}$ とすれば $P=e t \sigma_{Y} / S$ の形で $\mathrm{P}$ を決 めることが出来る。

1）䉆尾・黑羽：建論：第 69 号（昭和 36 年 10 月） 